\title{
A RELIABLE METHOD OF QUANTIFICATION OF TRACE COPPER IN BEVERAGES WITH AND WITHOUT ALCOHOL BY SPECTROPHOTOMETRY AFTER CLOUD POINT EXTRACTION
}

\author{
Ramazan Gürkan* and Nail Altunay \\ University of Cumhuriyet, Faculty of Science, Department of Chemistry, TR-58140, Sivas, Turkey
}

Recebido em 8/1/13; aceito em 4/4/13; publicado na web em 13/6/13

\begin{abstract}
A new cloud point extraction (CPE) method was developed for the separation and preconcentration of copper (II) prior to spectrophotometric analysis. For this purpose, 1-(2,4-dimethylphenyl) azonapthalen-2-ol (Sudan II) was used as a chelating agent and the solution $\mathrm{pH}$ was adjusted to 10.0 with borate buffer. Polyethylene glycol tert-octylphenyl ether (Triton X-114) was used as an extracting agent in the presence of sodium dodecylsulphate (SDS). After phase separation, based on the cloud point of the mixture, the surfactant-rich phase was diluted with acetone, and the enriched analyte was spectrophotometrically determined at 537 $\mathrm{nm}$. The variables affecting CPE efficiency were optimized. The calibration curve was linear within the range $0.285-20 \mu \mathrm{g} \mathrm{L}^{-1}$ with a detection limit of $0.085 \mu \mathrm{g} \mathrm{L}{ }^{-1}$. The method was successfully applied to the quantification of copper in different beverage samples.
\end{abstract}

Keywords: copper; beverage samples; cloud point extraction.

\section{INTRODUCTION}

Copper (II) is one of the most important heavy metals, and a microelement in mammalian nutrition. In general, a daily copper intake of 1.5-2.0 mg is essential. However, copper becomes toxic to humans if a large amount is ingested and accumulated in the tissue. For example, because of its mobilization and redox activity, catalytic copper is believed to play an important role in the formation of reactive oxygen species (ROS), such as superoxide anion $\left(\mathrm{O}_{2}^{-}\right)$and $\mathrm{OH}$ radicals. These radicals bind very quickly to DNA and create damage by breaking the DNA strands or modifying the bases and/ or deoxyribose, leading to carcinogenesis. ${ }^{1}$ Overexposure to copper causes ptyalism, nausea, vomiting, epigastric burning, and diarrhea. High doses of copper result in a series of systematic toxic effects such as hemolysis, hepatic neurosis, gastrointestinal bleeding, oliguria azotemia, hemoglobinuria, hematuria, proteinuria, hypertension, tachycardia, convulsions, and coma. ${ }^{2}$ Therefore, the trace amount of copper present in water must be controlled on a daily basis. In view of this, the separation and determination of copper from associated elements is essential. Moreover, the determination of copper levels both in serum and urine samples is of great importance in the early diagnosis of certain diseases. ${ }^{3}$

The concentration of copper ions can be analyzed using many techniques. Among them, flame atomic absorption spectrometry (FAAS) is a convenient technique and is available in most laboratories. FAAS has a number of advantages over other methods, including a higher tolerance to interferences and greater instrumentation simplicity. However, direct determination of copper in liquid foods or biological samples by FAAS is difficult due to its low sensitivity. ${ }^{4}$ In many instances, the technique demands pre-concentration prior to analysis. ${ }^{5,6}$

From a practical point of view, to be applied to the in situ analysis of aqueous samples such as liquid foods and beverages, a method must be rapid, simple, and should not require complicated pretreatments. In the case of copper, a limit of detection of at least $0.5 \mathrm{mg} \mathrm{L}^{-1}$ is required. ${ }^{7}$ The methods of inductively coupled plasma atomic emission spectrometry (ICP-AES $)^{8,9}$ or inductively coupled plasma mass spectrometry (ICP-MS $)^{10}$ provide sufficient detection

*e-mail: rgurkan95@gmail.com limits (approximately $6 \mu \mathrm{g} \mathrm{L} \mathrm{L}^{-1}$ for ICP-AES, $1.0 \mu \mathrm{g} \mathrm{L} \mathrm{L}^{-1}$ for ICP-MS). However, these methods require expensive instrumentation, and are therefore not suitable for the analysis of a large number of samples. Other methods including electrothermal/graphite furnace atomic absorption spectroscopy (ETV-AAS or GFAAS), ${ }^{11} \mathrm{X}$-ray fluorescence, ${ }^{12}$ differential pulse anodic (or cathodic) stripping voltammetry, ${ }^{13}$ electrothermal atomic absorption spectrometry (ETAAS),${ }^{14}$ flame atomic absorption spectrometry (FAAS) $)^{15-17}$ and evanescent wave absorption spectroscopy ${ }^{18}$ have also been developed to measure copper content, but neither the instruments nor the techniques tend to be familiar for routine analysis.

Among these sensitive methods, spectrophotometry in UV-visible region is a tool that is most widely used in developing countries due to its low cost, easy operation, high accuracy and precision, and good selectivity particularly when a selective chromogenic chelating agent for analyte is used. However, the direct determination of $\mathrm{Cu}$ by spectrophotometry can be problematic since its sensitivity is not sufficient for samples with low abundance levels of $\mathrm{Cu}$. For this reason, an extraction and enrichment step is often required before spectrophotometric determination of the analyte.

Sample preparation is one of the most important and crucial steps in a complete analytical process. Until now, several sample preparation methods have been developed for the determination of trace $\mathrm{Cu}$ from various sample matrices, including liquid-liquid extraction (LLE), ${ }^{19}$ solid-phase extraction (SPE),${ }^{20}$ cloud point extraction (CPE), ${ }^{21,22}$ membrane filtration, ${ }^{23}$ and ion exchange. ${ }^{24}$

Recently, the CPE using non-ionic surfactants has attracted considerable attention as an alternative to the conventional extraction techniques for separation and preconcentration. ${ }^{25-27}$ Briefly, above the cloud-point temperature, the surfactant solution is easily separated into two distinct phases: a surfactant-rich phase with a small volume and a diluted aqueous phase, in which the surfactant concentration is close to the critical micelle concentration (CMC). When a metal ion forms a hydrophobic complex with an appropriate chelating reagent under appropriate conditions, the hydrophobic complex can be trapped in the hydrophobic micelle core, and then extracted into the surfactant-rich phase. As a new separation technique, CPE offers many advantages over traditional liquid-liquid extraction, such as its simplicity, low cost, and speed, as well as its lack of requirement for organic solvents and its high capacity 
to concentrate a wide variety of analytes with high recoveries and high concentration factors. ${ }^{28}$

When the CPE technique has been used for the extraction of metal chelates, spectrophotometry has often been used as the analytical technique. ${ }^{29-32}$ Though spectrophotometry has poor sensitivity, it is a very simple, rapid, and low-cost analytical tool, which can be found in almost every analytical research laboratory. CPE is also a very simple, rapid, and environmentally friendly separation and preconcentration procedure with a high enrichment factor. A combination of CPE with spectrophotometry leads to a very simple, rapid and low-cost analytical method with adequate sensitivity and selectivity.

In this context, the main aim of the current study was to evaluate the feasibility of combining CPE preconcentration with spectrophotometry at $537 \mathrm{~nm}$ for the quantification of trace copper(II) in beverage samples. In this procedure, Sudan II was used as the chelating agent and Triton $\mathrm{X}-114$ as the extracting agent in the presence of SDS at $\mathrm{pH} 10$. The chemical variables affecting CPE were investigated in detail. The method developed was successfully applied to the determination of trace copper in a number of alcoholic and nonalcoholic beverage samples.

\section{EXPERIMENTAL}

\section{Instrumentation}

Absorbance measurements at the selected wavelengths, 537 and $490 \mathrm{~nm}$, were performed on a double-beam UV-Visible Spectrophotometer (Shimadzu UV-1800 PC, Kyoto, Japan) equipped with the $1.0-\mathrm{cm}$ quartz cells. The $\mathrm{pH}$ measurements were performed using a $\mathrm{pH}$ meter (Sartorious Docu-pH-meter). A centrifuge (Universal 320 model, Hettich) was used to accelerate the phaseseparation process. A thermostatic water bath (MF120, Nuve) was used to maintain the temperature in the $\mathrm{CPE}$ experiments. A programmable ultrasonic water bath at $35 \mathrm{kHz}$, Model No.SC121TH (Sonicor, Deep Park, NY, USA) as well as a hot plate and membrane filter (25 $\mathrm{mm}$ in diameter, porosity $0.45 \mu \mathrm{m}$, Dura Pore TM, Millipore) used to preheat and filter through samples prior to analysis, was used to remove the dissolved gases from beer samples.

\section{Reagents and solutions}

A stock standard copper (II) solution (1000 $\mathrm{mg} \mathrm{L}^{-1}$ ) was prepared by dissolving appropriate amounts of copper nitrate $\left(\mathrm{Cu}\left(\mathrm{NO}_{3}\right)_{2} \times 3 \mathrm{H}_{2} \mathrm{O}\right)$ (Merck, Darmstadt, Germany) in bidistilled water. Working standard solutions were obtained by stepwise dilution of the stock standard solution just prior to use. A $2.0 \times 10^{-3} \mathrm{~mol} \mathrm{~L}^{-1}$ solution of Sudan II (Sigma, St. Louis, MO, USA) was prepared by dissolving a suitable amount of solid reagent in $5.0 \mathrm{~mL}$ ethanol (Merck, Darmstadt, Germany) and diluting to $100 \mathrm{~mL}$ with water. The solution was kept in a refrigerator $\left(4^{\circ} \mathrm{C}\right)$ when not in use. Solutions $\left(1.0 \times 10^{-3} \mathrm{~mol} \mathrm{~L}^{-1}\right)$ of cetylpyridinium chloride (CPC), cetyltrimethylammonium bromide (CTAB), and SDS (Sigma, St. Louis, MO, USA) were prepared by dissolving a suitable amount of each surfactant in $100 \mathrm{~mL}$ of water. Solutions $(5.0 \%$, volume for volume $[\mathrm{v} / \mathrm{v}])$ of Triton X-114, polyoxyethylene p-t-octylphenol (Triton X-100), and polyethyleneglycolmono- $p$-nonylphenylether (Ponpe 7.5) (Sigma, St. Louis, MO, USA) were prepared in water and were used without further purification. 2-Octanol (Sigma, St. Louis, MO, USA), was used to prevent the foaming often encountered in the analysis of beer samples. A $0.05-\mathrm{mol} \mathrm{L}^{-1}$ borate buffer solution ( $\mathrm{pH} 10$ ) was prepared by mixing $59.0 \mathrm{~mL}$ of $0.05 \mathrm{~mol} \mathrm{~L}^{-1}$ sodium tetraborate solutions with $41.0 \mathrm{~mL}$ of $0.1 \mathrm{~mol} \mathrm{~L}^{-1} \mathrm{NaOH}$ solution in $100-\mathrm{mL}$ volumetric flask. All other chemicals and reagents used in this study, such as $\mathrm{H}_{2} \mathrm{O}_{2}$ and $\mathrm{HNO}_{3}$, were of analytical-reagent grade or higher purity.

\section{Samples and sample preparation}

All beverage samples selected for analysis were supplied from local markets in Sivas, Turkey. Initially, all of the glassware and other mineralization containers used were acid-washed to avoid contamination. A $0.1 \%(\mathrm{v} / \mathrm{v}) 2$-octanol solution was added to the beer sample to prevent foaming and the beer samples were degassed for 15 min using an ultrasonic bath. Wine samples were de-alcoholized at $80^{\circ} \mathrm{C}$ using a reduced pressure evaporator until its total volume was approximately a quarter of its initial volume $(100 \mathrm{~mL})$. The nonalcoholic beverages were filtered using a membrane filter $(0.45-\mu \mathrm{m}$ pore size $)$ to remove suspended solids before analysis.

The applicability of the method was demonstrated by the analysis of beverage samples and two certified reference materials (CRMs). The samples were dissolved according to the methods described in previous studies. ${ }^{33}$

A suitable volume $(20-30 \mathrm{~mL})$ of a sample was accurately pipetted into a 50-mL acid-cleaned polytetrafluoroethylene (PTFE) beaker and a minimal volume of $0.05-\mathrm{mol} \mathrm{L}^{-1}$ nitric acid was added to the sample, followed by $2.0 \mathrm{~mL}$ of concentrated $\mathrm{HNO}_{3}$. The beaker was covered with a PTFE cover and heated on a hot plate at $120{ }^{\circ} \mathrm{C}$ for $3 \mathrm{~h}$. After cooling to room temperature, the interior surface of the cover was washed with $1.0 \mathrm{~mL}$ of concentrated $\mathrm{HNO}_{3}$ into the beaker and $2.0 \mathrm{~mL}$ of $35 \%(\mathrm{w} / \mathrm{w}) \mathrm{H}_{2} \mathrm{O}_{2}$ (Merck, Darmstadt, Germany) was added dropwise. The beaker was heated at $100{ }^{\circ} \mathrm{C}$ for $30 \mathrm{~min}$, and then temperature was gradually raised to $130{ }^{\circ} \mathrm{C}$ and maintained at this temperature until complete decomposition of sample was achieved. If this was not completed, a further $1.5 \mathrm{~mL}$ of concentrated $\mathrm{HNO}_{3}$ and $1.0 \mathrm{~mL} \mathrm{H}_{2} \mathrm{O}_{2}$ were added and the above procedure was repeated to dissolve the residue.

After complete decomposition of the sample, $0.05-\mathrm{mol} \mathrm{L}^{-1} \mathrm{HNO}_{3}$ with a sufficient volume and $1.0-\mathrm{mL}_{2} \mathrm{O}_{2}$ were added and heated at $100{ }^{\circ} \mathrm{C}$ gently until the solution was clear. The resulting solution (nearly $2.5 \mathrm{~mL}$ ) was then transferred into 10-, 20-, and 50-mL calibrated flasks by washing the interior surface of the beaker with $0.05-\mathrm{mol} \mathrm{L}^{-1}$ nitric acid three times and diluting with water (diluting at ratios of 1:5, 1:10, and 1:25 according to sample type). In order to control a systematic error originating from analyte-matrix interactions, standard $\mathrm{Cu}$ solutions at levels ranging from of 5 to $15 \mu \mathrm{g} \mathrm{L}^{-1}$ were also spiked into the digested and diluted beverage samples.

Then, the accuracy of results was verified by evaluating whether or not the percentage recoveries are quantitative. The above-mentioned two wet digestion procedures for $3-5 \mathrm{~mL}$ of the diluted samples were repeated five times in order to dissolve the samples and were subjected to CPE prior to spectrophotometric detection.

A blank analysis was also carried out using the above decomposition procedures to correct for any analyte contaminants in the reagents used for sample preparation.

A portion $(0.5 \mathrm{~g})$ of CRMs, SRM 1570a spinach leaves and SRM 1573a tomato leaves was charged into a 100-mL PTFE beaker. The samples were dissolved in a similar way. For dissolution, a minimal volume of $0.05 \mathrm{~mol} \mathrm{~L}^{-1}$ nitric acid was added to moisten the sample thoroughly, followed by $3.0 \mathrm{~mL}$ of concentrated $\mathrm{HNO}_{3}$. The beaker was heated on a hot plate at approximately $130{ }^{\circ} \mathrm{C}$ for $3 \mathrm{~h}$. After cooling to room temperature, $2.0 \mathrm{~mL}$ of concentrated $\mathrm{H}_{2} \mathrm{O}_{2}$ was added dropwise. The beaker was heated until complete decomposition of sample. The resulting solution was transferred into a $50-\mathrm{mL}$ volumetric flask by washing the interior of the beaker with small portions of $0.05-\mathrm{mol} \mathrm{L}^{-1} \mathrm{HNO}_{3}$, and the solution was diluted to the mark with $0.05 \mathrm{~mol} \mathrm{~L}^{-1} \mathrm{HNO}_{3}$. For the purposes of comparison, the same digestion procedure was also conducted for all beverage samples including $\mathrm{CRMs}$ using $\mathrm{HClO}_{4}$ instead of $\mathrm{H}_{2} \mathrm{O}_{2}$ at volume ratio of $4: 1$. 


\section{Procedure for CPE}

Suitable aliquots of sample or standard $\mathrm{Cu}$ (II) solution, $0.8 \mathrm{~mL}$ of $2.0 \times 10^{-3} \mathrm{~mol} \mathrm{~L}^{-1}$ Sudan II solution, $0.1 \mathrm{~mL}$ of $1.0 \times 10^{-3} \mathrm{~mol} \mathrm{~L}^{-1} \mathrm{SDS}$, and $0.4 \mathrm{~mL}$ of $5.0 \%(\mathrm{v} / \mathrm{v})$ Triton $\mathrm{X}-114$ solution were added into a 50 - $\mathrm{mL}$ calibrated centrifuge tube, and the mixture was buffered to $\mathrm{pH}$ 10 with $0.9 \mathrm{~mL}$ of $0.05 \mathrm{~mol} \mathrm{~L}^{-1}$ borate buffer, and then diluted to 50 $\mathrm{mL}$ with water. The resultant solution was kept in a thermostatic water bath at $55^{\circ} \mathrm{C}$ for $10 \mathrm{~min}$; separation of the aqueous and surfactant-rich phase was accomplished by centrifugation for $10 \mathrm{~min}$ at $5142.7 \mathrm{~g}$. After cooling in an ice bath, the surfactant-rich phase became viscous and the supernatant aqueous phase was then separated completely using a syringe centered in the tube. To decrease the viscosity of the surfactant-rich phase, the surfactant-rich phase was diluted to $1.0 \mathrm{~mL}$ with acetone, and then the absorbance of the resultant solution was measured by spectrophotometer at $537 \mathrm{~nm}$ against reagent blank for determination of copper. Finally, the copper contents of the beverage samples were determined using the calibration curve and standard addition calibration curve procedure when necessary.

\section{RESULTS AND DISCUSSION}

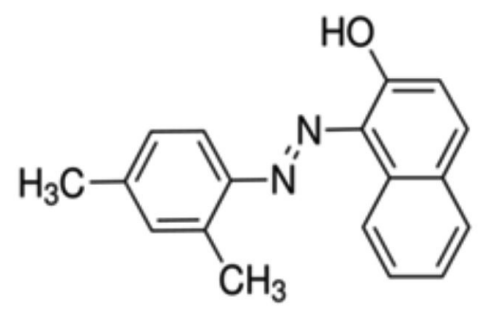

Figure 1. The chemical structure of Sudan II

Sudan II, as can be seen from Figure 1, is a hydroxy-azo dye containing azo $-\mathrm{N}=\mathrm{N}$ - and phenolic $-\mathrm{OH}$ groups as functional groups. It displays tautomeric behavior, which is known as azo-hydrazone tautomerism, in various media by the intramolecular proton transfer between nitrogen and oxygen atoms. ${ }^{34}$ The presence of azo-hydrazone tautomerism in Sudan II has a considerable influence on its unique photo-physical properties, which is in turn strongly influenced by several factors including temperature, structure of substituents, and solvent polarity. ${ }^{34}$ Sudan II is a weak acid. However, the azo group in the 1-position, which acts as a proton acceptor, leads to formation of an intramolecular hydrogen bond with the phenolic -OH group. This additional stabilization of the neutral Sudan II molecule is responsible for a rather high $\mathrm{p} K_{\mathrm{a}}$ value of $11.65 .^{35}$ It is explained in another study that Sudan dyes also possess two reducible groups: a nitrogen-nitrogen double bond and a phenol group. The latter is transformed into a phenate ion at a sufficiently high $\mathrm{pH}$ and becomes reducible and, thus, could be oxidized by $\mathrm{Ag}^{+}$ions. In the relevant study, a visual light scattering detection method based on the formation of silver nanoparticles (NPs) at $452 \mathrm{~nm}$ was proposed for the monitoring of Sudan dyes in food products after deoxidization of $\mathrm{Ag}^{+}$ions to brown silver NPs. ${ }^{36} \mathrm{~A}$ similar reduction process, which corresponds to a spontaneous auto-reduction of the $\mathrm{Cu}^{2+}$ into $\mathrm{Cu}^{+}$, was also observed in the cases of complexation of $\mathrm{Cu}^{2+}$ ions with the 6,6-dimethyl-2,2-bipyridine, ${ }^{37} \beta$-ketoimine calyx[4]arene, ${ }^{38}$ and Sudan I. ${ }^{39}$ In a later study, it is implied that the $\mathrm{Cu}(\mathrm{I})$-Sudan I complex formed after prereduction of copper (II) in alkaline media at $50{ }^{\circ} \mathrm{C}$ is a positively charged metal-ligand complex with a $1: 1$ stoichiometric ratio by means of cyclic voltammetric, UV-visible and IR spectrophotometric studies. Because of these features of Sudan dyes, Sudan II is considered as a chromogenic chelating and redox sensitive agent in spectrophotometric detection of copper after preconcentration with CPE. Our preliminary CPE tests have also revealed that it forms a stable ternary complex of sufficient hydrophobicity to be quantitatively extracted into a small volume of a Triton $\mathrm{X}-114$ surfactant-rich phase in the presence of SDS as a sensitivity enhancement surfactant, thus reaching the desired preconcentration level. Thus, we decided to optimize the experimental conditions for the selective spectrophotometric determination of copper (II) at 537 $\mathrm{nm}$ after preconcentration with CPE using the Sudan II-SDS-Triton $\mathrm{X}-114$ micellar system.

\section{Optimization study}

In order to apply the CPE procedure developed to the quantification of trace copper from different beverage matrices, with and without alcohol, the analytical variables affecting CPE efficiency have been optimized.

\section{Effect of pH}

Sudan II is a weak acidic reagent $\left(\mathrm{pK}_{\mathrm{a}}: 11.65\right)$ and its dissociation equilibrium depends on the $\mathrm{pK}_{\mathrm{a}}$ value as well as the $\mathrm{pH}$ of the solution. Hence, its complex formation and extraction behavior is also $\mathrm{pH}$ dependent. The effect of $\mathrm{pH}$ on the signal intensity of copper (II) in the surfactant-rich phase was evaluated at $\mathrm{pH}$ values varying from 5.0 to 11.0 . The variation of $\mathrm{pH}$ was initially achieved using BrittonRobinson buffer solutions $\left(0.04 \mathrm{~mol} \mathrm{~L}^{-1}\right)$ of different $\mathrm{pH}$ values. As can be seen from Figure 2, the quantitative maximum extraction of copper (II) was achieved at a $\mathrm{pH}$ of 10.0. At lower and higher $\mathrm{pH}$ values, the hydrophobic complex of $\mathrm{Cu}$ (II)-Sudan II does not form completely, so the extraction efficiency of copper(II) is low. Hence, $\mathrm{pH} 10.0$ was selected as the optimal working value for further studies.

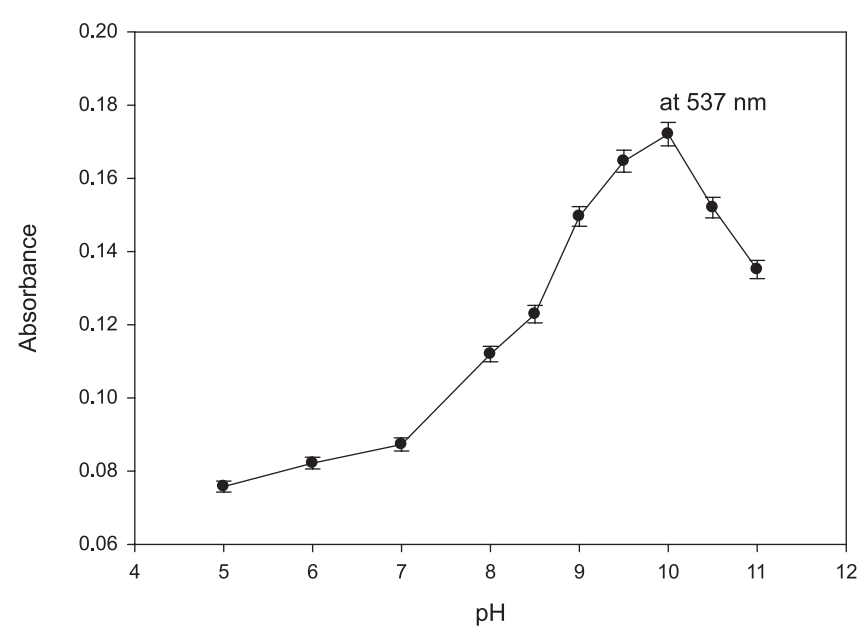

Figure 2. Effect of $p H$ on the signal intensity in surfactant-rich phase. Conditions: $\mathrm{Cu}(\mathrm{II}), 10 \mu \mathrm{g} \mathrm{L} \mathrm{L}^{-1}$; $1.0 \mathrm{~mL}$ of $2.0 \times 10^{-3} \mathrm{~mol} \mathrm{~L}^{-1}$ Sudan II solution; 0.125 $\mathrm{mL}$ of $1.0 \times 10^{-3} \mathrm{~mol} \mathrm{~L} L^{-1} \mathrm{SDS}, 0.5 \mathrm{~mL}$ of $5.0 \%(\mathrm{v} / \mathrm{v})$ Triton $\mathrm{X}-114$; equilibrium temperature, $55^{\circ} \mathrm{C}$ and incubation time, $10 \mathrm{~min}$. The error bars indicate standard deviations of three replicate measurements

In order to determine the best buffer solution at $\mathrm{pH} 10.0$, several buffer systems, including $\mathrm{HCO}_{3}{ }^{-} / \mathrm{CO}_{3}{ }^{2}, \mathrm{NH}_{3} / \mathrm{NH}_{4} \mathrm{Cl}$, and sodium tetraborate/ $\mathrm{NaOH}$ at isomolar concentrations of $0.05 \mathrm{~mol} \mathrm{~L}^{-1}$ as well as B-R buffer were studied. The best analytical sensitivity was obtained in the presence of borate buffer. Next, the effect of buffer volume on analytical sensitivity was studied in the range 0.3-3.0 mL, and the maximum absorbance was obtained at a buffer volume of $0.9 \mathrm{~mL}$. The results are shown in Figure 3. In buffer volumes lower and higher 
than $0.9 \mathrm{~mL}$, the absorbance sharply decreased. The sharp reduction in absorbance in higher buffer volumes may reversibly be due to the gradual dissociation of a hydrophobic ternary complex formed in the presence of SDS with increasing ionic strength, whereas at lower buffer volumes a stable complex with sufficient hydrophobicity to be extracted into a small volume of a surfactant-rich phase cannot be obtained at $\mathrm{pH}$ 10.0. Therefore, it was decided to use a borate buffer volume of $0.9 \mathrm{~mL}$ for further studies.

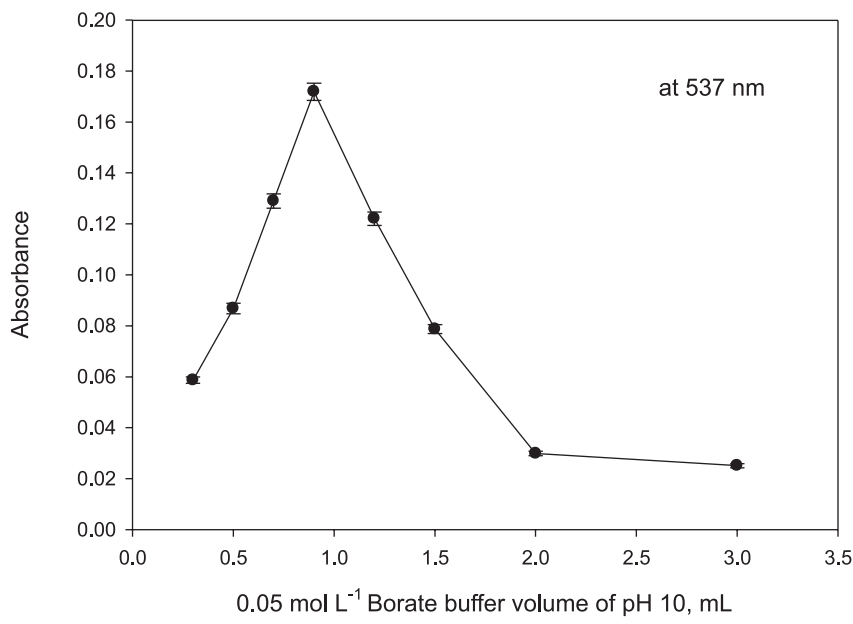

Figure 3. Effect of buffer volume on the signal intensity in surfactant-rich

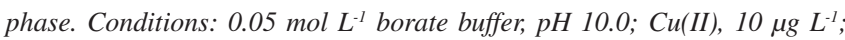
$1.0 \mathrm{~mL}$ of $2.0 \times 10^{-3} \mathrm{~mol} \mathrm{~L}^{-1}$ Sudan II solution; $0.125 \mathrm{~mL}$ of $1.0 \times 10^{-3} \mathrm{~mol} \mathrm{~L}^{-1}$ SDS, $0.5 \mathrm{~mL}$ of $5.0 \%(\mathrm{v} / \mathrm{v})$ Triton $\mathrm{X}$-114; equilibrium temperature, $55^{\circ} \mathrm{C}$ and incubation time, $10 \mathrm{~min}$. The error bars indicate standard deviations of three replicate measurements

\section{Effect of Sudan II concentration}

The CPE efficiency depends on the hydrophobicity of the ligand and the complex formation, the apparent equilibrium constants in the micelle medium, the kinetics of the complex formation, and the mass transfer between the phases. The variation of the analytical signal as a function of ligand volume of $2.0 \times 10^{-3} \mathrm{~mol} \mathrm{~L}^{-1}$ in the range $0.2-2.5 \mathrm{~mL}$ was studied, and the results are represented in Figure 4. It can be seen that the analytical signal of copper (II) reaches to a maximum and then gradually decreases with increasing reagent volume when the ligand volume is $0.9 \mathrm{~mL}$. The reduction in extraction efficiency with greater amounts of chelating agent may be due to the extraction of the ligand itself, which can easily saturate the small volume of extraction solvent. Another reason may be the aggregation of dye molecules depending on their increasing concentration by means of dipole-dipole interactions and formation of intermolecular hydrogen bonding. Hence, a ligand volume of $0.9 \mathrm{~mL}$ was chosen as the optimal value for further studies.

\section{Effect of nonionic and ionic surfactant concentration}

Surfactants have been used efficiently to extract metal-ligand complexes without using organic solvents. ${ }^{40}$ Hence, an attempt was made to extract the metal-chelate complex from the aqueous solution using two types of surfactants. These surfactants are known to form aggregates, which are called micelles, and these entrap the complexes very efficiently to cause phase separation. Several surfactants have been tried to separate the metal-ligand complex from the aqueous phase. After adding the surfactant, the solutions were heated to different temperatures to cause cloud-point formation. Once clouding takes place, the phase separation can efficiently be carried out using

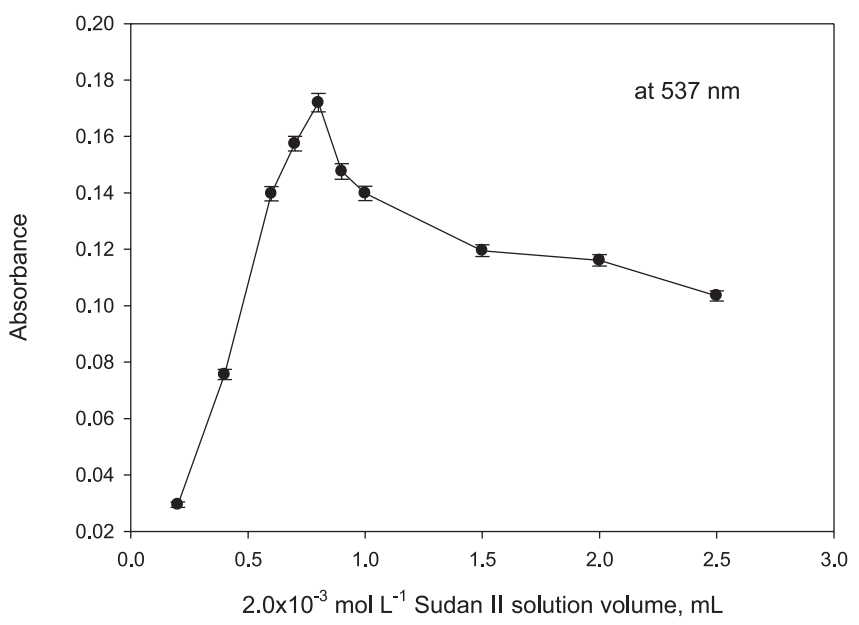

Figure 4. Effect of Sudan II concentration on the signal intensity in surfactant-

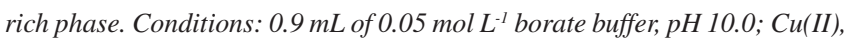
$10 \mu \mathrm{g} \mathrm{L} \mathrm{L}^{-1} ; 0.125 \mathrm{~mL}$ of $1.0 \times 10^{-3} \mathrm{~mol} \mathrm{L^{-1 }} \mathrm{SDS}, 0.5 \mathrm{~mL}$ of $5.0 \%$ (v/v) Triton $X-114$; equilibrium temperature, $55^{\circ} \mathrm{C}$ and incubation time, $10 \mathrm{~min}$. The error bars indicate standard deviations of three replicate measurements

a simple centrifugation procedure. Triton X-100, Triton X-114, and Ponpe 7.5 were used preferentially for the efficient phase separation. From the three surfactants used, only Triton X-114 could cause the best quantitative extraction with maximum absorbance after heating to $55^{\circ} \mathrm{C}$. Since the complex is ionic in nature, only in the presence of ionic surfactants as counter ions may the use of nonionic surfactants, Triton X-114, Ponpe 7.5, and Triton X-100 significantly facilitate the quantitative extraction of the metal chelate complex.

Among the nonionic surfactants used, Triton X-114 gave a higher absorbance value to the sample when compared with other surfactants; hence, Triton X-114 was preferred as an extracting solvent in all further studies. The effect of Triton X-114 concentration on the extraction of the complex was investigated by varying its concentration by the addition of $0.05-1.5 \mathrm{~mL}$ of $5.0 \%(\mathrm{v} / \mathrm{v})$ solution. As can be seen from Figure 5, extraction of the complex increased with concentration up to $0.4 \mathrm{~mL}$ for Triton X-114 $(0.3$ and $0.4 \mathrm{~mL}$ for Triton $\mathrm{X}-100$ and Ponpe 7.5 , respectively); thereafter sample absorbance values

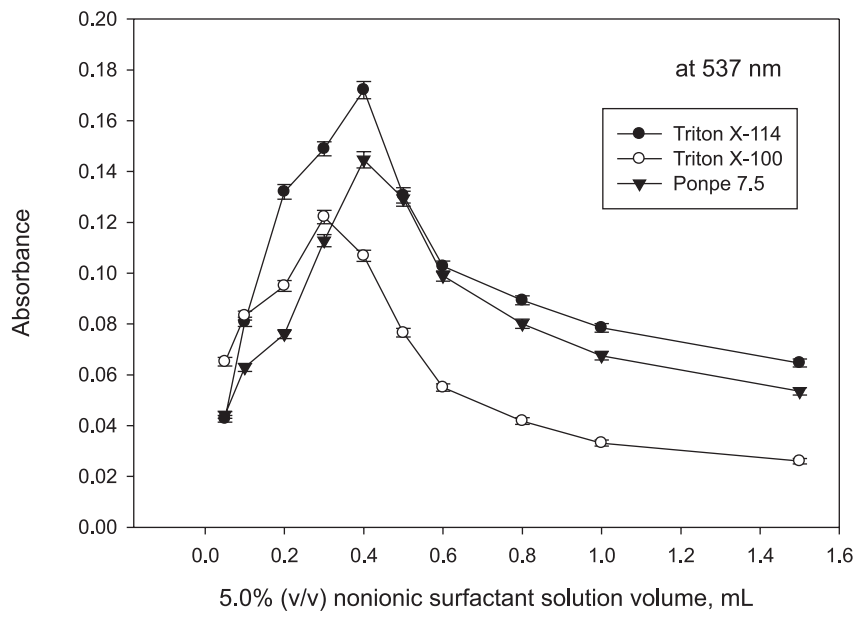

Figure 5. Effect of nonionic surfactant volume on the extraction of ion-associate complex with CPE. Conditions: $0.9 \mathrm{~mL}$ of $0.05 \mathrm{~mol} \mathrm{L^{-1 }}$ borate buffer, $\mathrm{pH}$ 10.0; $\mathrm{Cu}(\mathrm{II}), 10 \mu \mathrm{g} \mathrm{L^{-1 }}$; $0.8 \mathrm{~mL}$ of $2.0 \times 10^{-3} \mathrm{~mol} \mathrm{~L}^{-1}$ Sudan II; $0.1 \mathrm{~mL}$ of $1.0 \times 10^{-3}$ mol $L^{-1} S D S$; equilibrium temperature, $55^{\circ} \mathrm{C}$ and incubation time, $10 \mathrm{~min}$. The error bars indicate standard deviations of three replicate measurements 
gradually decreased (Figure 5). At concentrations higher than $0.4 \mathrm{~mL}$ of $5.0 \%(\mathrm{v} / \mathrm{v})$, the analytical signal decreased, probably due to the increase of the surfactant volume, which deteriorates the analytical signal. At concentrations below this value, the extraction efficiency of the complex was low because there are few surfactant molecules to entrap quantitatively the positively charged copper complex in the presence of SDS behaving as an auxiliary ligand. Hence, $0.4 \mathrm{~mL}$ of $5.0 \%(\mathrm{v} / \mathrm{v})$ Triton $\mathrm{X}-114$ has been fixed as the optimum value where the sample absorbance was high with low analyte blank.

Ionic surfactants such as CPC, CTAB, and SDS were used to extract quantitatively the charged copper complex from the aqueous phase and to improve the analytical sensitivity in the presence of Triton X-114. In presence of ionic surfactants, absorbance initially decreased with increasing slope in the range $0.01-0.1$ (or 0.2 ) $\mathrm{mL}$ of $1.0 \times 10^{-3} \mathrm{~mol} \mathrm{~L}^{-1}$, giving a maximum signal, while in larger volumes than 0.1 or $0.2 \mathrm{~mL}$ absorbance decreased with a constant slope (Figure 6). However, the best absorbance signal was obtained for SDS with $0.1 \mathrm{~mL}$ of $1.0 \times 10^{-3}$ mol L $\mathrm{L}^{-1}$. The reason for this increase in absorbance may be the electrostatic interactions between the positively charged $\mathrm{Cu}$-ligand complex and negatively charged SDS molecules to give a ternary complex with hydrophobic character. Hence, $0.1 \mathrm{~mL}$ of $1.0 \times 10^{-3} \mathrm{~mol} \mathrm{~L}^{-1} \mathrm{SDS}$ as a sensitivity enhancement surfactant was selected for further studies.

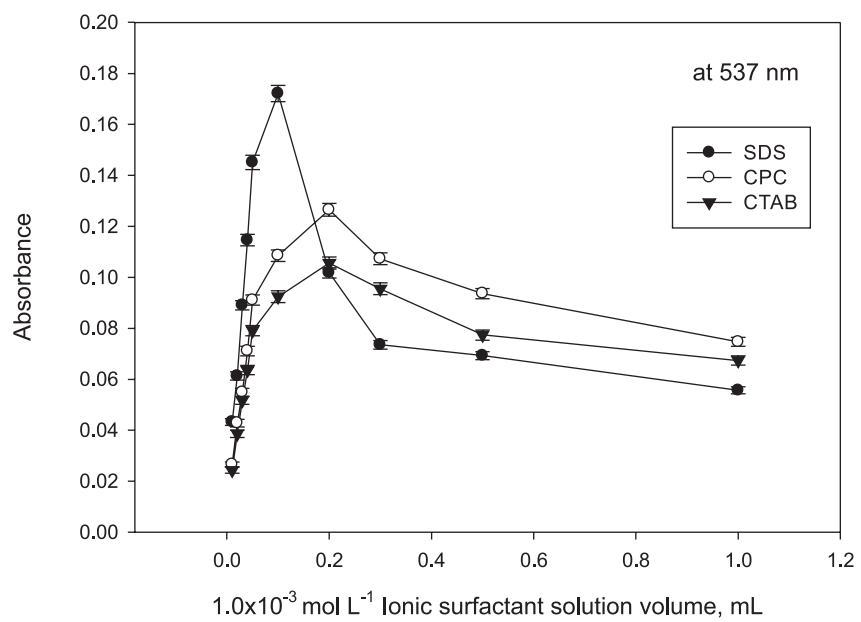

Figure 6. Effect of ionic surfactant volume on the extraction of ion-associate complex with CPE. Conditions: $0.9 \mathrm{~mL}$ of $0.05 \mathrm{~mol} \mathrm{~L}^{-1}$ borate buffer, $\mathrm{pH} 10.0$; $\mathrm{Cu}(\mathrm{II}), 10 \mu \mathrm{g} \mathrm{L}{ }^{-1} ; 0.8 \mathrm{~mL}$ of $2.0 \times 10^{-3} \mathrm{~mol} \mathrm{~L}^{-1}$ Sudan II; $0.5 \mathrm{~mL}$ of $5.0 \%(\mathrm{v} / \mathrm{v})$ Triton $\mathrm{X}$-114; equilibrium temperature, $55^{\circ} \mathrm{C}$ and incubation time, $10 \mathrm{~min}$. The error bars indicate standard deviations of three replicate measurements

\section{Effect of ionic strength}

In order to investigate the effect of ionic strength on CPE performance, various experiments were performed by adding different amounts of $\mathrm{NaCl}\left(0.005-0.05 \mathrm{~mol} \mathrm{~L}^{-1}\right)$. Other experimental conditions were kept constant during the analysis. The results showed that ionic strength has no significant effect on the enrichment factor up to a concentration of $0.01 \mathrm{~mol} \mathrm{~L}^{-1}$. Thus, ionic strength was kept constant at a salt concentration of $0.01 \mathrm{~mol} \mathrm{~L}^{-1}$ in order to obtain precise and stable analytical signals.

\section{Effect of equilibrium temperature and time}

It is desirable to have the shortest incubation time and the lowest possible equilibration temperature, which compromise completion of the reaction and efficient separation of the phases. The effect of equilibrium temperature was investigated in temperature range $20-70{ }^{\circ} \mathrm{C}$.
It was found that the solutions became turbid as soon as the solutions were put into the water bath with a temperature higher than $50^{\circ} \mathrm{C}$, and the temperature had no notable effect upon the extraction efficiency and the analytical signal remained constant within the temperature range $50-55{ }^{\circ} \mathrm{C}$. In higher temperatures than $55^{\circ} \mathrm{C}$, the extraction efficiency gradually and significantly decreased. Thus, $55^{\circ} \mathrm{C}$ was selected as the equilibrium temperature. Maintaining the equilibrium temperature of $55^{\circ} \mathrm{C}$, the influence of incubation time on CPE was studied within the range 5-30 min. It was observed that, $10 \mathrm{~min}$ was sufficient to achieve a quantitative extraction of the analyte. Thus, an incubation time of $10 \mathrm{~min}$ was employed for the CPE procedure.

The effect of centrifugation time upon extraction efficiency at 5142.7 g was studied for time interval 5-30 min. A centrifugation time of 10 min was selected for the entire procedure, since the analyte extraction during this time is almost quantitative. The results obtained were chosen as optimal because they yielded the greatest precision.

\section{Effect of diluent agent type}

Different solvents such as acetone, THF, acetonitrile, methanol, ethanol, and acidic solutions of ethanol and methanol were tried to select the one that could completely dissolve the surfactant-rich phase and the extracted materials (complex of copper and excess of ligand) and give the best analytical sensitivity and correlation coefficient for calibration curves constructed between absorbance and copper concentrations of $0.03,0.05$, and $0.1 \mathrm{~mL}$ of $10 \mathrm{mg} \mathrm{L}^{-1}$ with a wavelength shift of $8 \mathrm{~nm}$. As the best results were obtained with acetone, this was chosen as the diluent for further experiments (Figure 7).

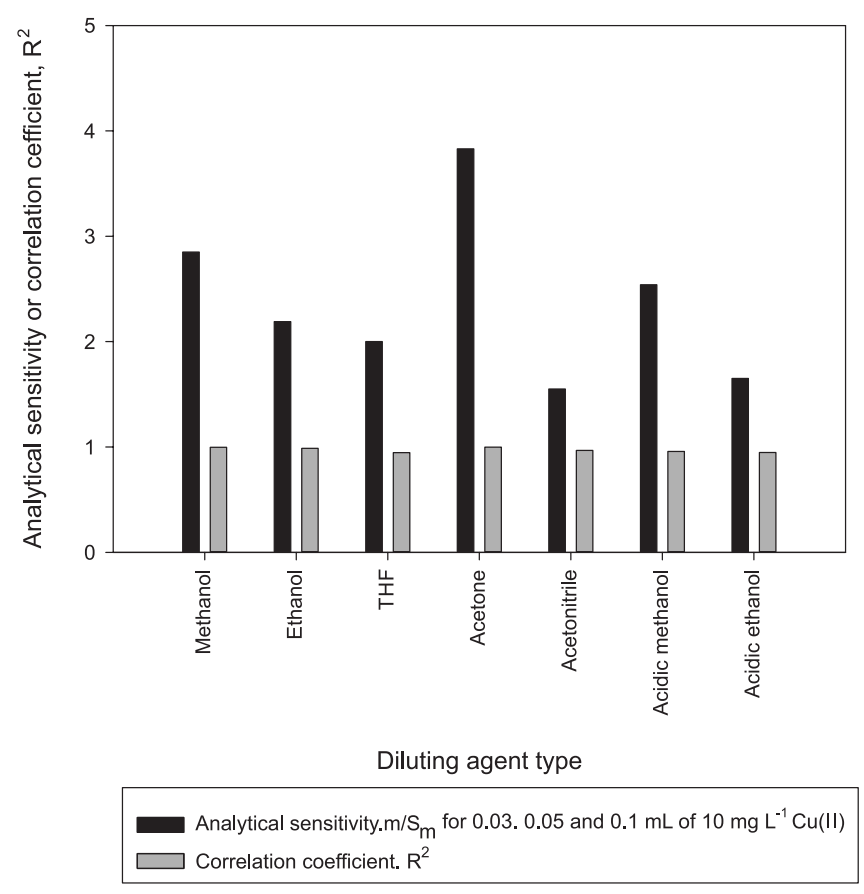

Figure 7. Effect of diluent agent on the signal intensity in surfactant-rich phase. Conditions: $0.9 \mathrm{~mL}$ of $0.05 \mathrm{~mol} \mathrm{~L}^{-1}$ borate buffer, $\mathrm{pH}$ 10.0; $\mathrm{Cu}(\mathrm{II}), 10$ $\mu \mathrm{g} \mathrm{L}^{-1}$; $0.8 \mathrm{~mL}$ of $2.0 \times 10^{-3} \mathrm{~mol} \mathrm{~L} \mathrm{~L}^{-1}$ Sudan II; $0.1 \mathrm{~mL}$ of $1.0 \times 10^{-3} \mathrm{~mol} \mathrm{~L}^{-1} \mathrm{SDS}$; $0.5 \mathrm{~mL}$ of $5.0 \%(\mathrm{v} / \mathrm{v})$ Triton $\mathrm{X}-114$; equilibrium temperature, $55^{\circ} \mathrm{C}$ and incubation time, $10 \mathrm{~min}$

\section{Analytical performance}

Under the optimized conditions, a calibration graph was constructed for copper by preconcentrating eight standard solutions 
according to the given procedure. The linear range was $0.285-20 \mu \mathrm{g}$ $\mathrm{L}^{-1}$ with a correlation coefficient of 0.9968 . The calibration function was $\mathrm{A}=0.0046\left[\mathrm{Cu}(\mathrm{II}), \mu \mathrm{g} \mathrm{L^{-1 }}\right]+0.1257$, where $\mathrm{A}$ is the absorbance. The limits of detection and quantification defined as $3 \mathrm{~S}_{\mathrm{b}} / \mathrm{m}$ and $10 \mathrm{~S}_{\mathrm{b}} / \mathrm{m}$ (where $\mathrm{S}_{\mathrm{b}}$ is the standard deviation of twelve replicate measurements of the blank and $\mathrm{m}$ is the slope of the calibration curve) were found to be 0.085 and $0.285 \mu \mathrm{g} \mathrm{L}^{-1}$, respectively. The precision for six replicate measurements at $0.5,2.0$, and $14 \mu \mathrm{g} \mathrm{L} \mathrm{L}^{-1}$ of copper with preconcentration was in the range $2.25-3.21 \%$ relative standard deviation. Other parameters related to the preconcentration systems were also calculated and are shown in Table 1 .

Table 1. Analytical characteristics of the proposed spectrophotometric method with and without $\mathrm{CPE}$

\begin{tabular}{lcc}
\hline \multirow{2}{*}{ Parameters } & \multicolumn{2}{c}{ with Sudan II } \\
\cline { 2 - 3 } & with CPE at $537 \mathrm{~nm}$ & without CPE at $490 \mathrm{~nm}$ \\
\hline Linear range & $0.2-20 \mu \mathrm{g} \mathrm{L}-1$ & $10-200 \mu \mathrm{g} \mathrm{L}{ }^{-1}$ \\
Slope & $4.6 \times 10^{-3}$ & $2.0 \times 10^{-4}$ \\
Intercept & 0.1257 & 0.037 \\
Correlation coefficient & 0.9968 & 0.9988
\end{tabular}

$\left(\mathrm{R}^{2}\right)$

Recovery \% (n: 3)

98.5-102.5

98.7-103.5

Precision, RSD (\%) (n: 5) 3.21, 2.79 and 2.25

$4.35,3.75$ and 2.65

$\left(0.5,2.0\right.$ and $\left.14 \mu \mathrm{g} \mathrm{L}^{-1}\right) \quad\left(25,75\right.$ and $\left.150 \mu \mathrm{g} \mathrm{L}^{-1}\right)$

*Limit of detection, LOD $\quad 0.085$

3.15

$\left(\mu \mathrm{g} \mathrm{L}{ }^{-1}\right)$

Limit of quantification, $\quad 0.285$

10.5

LOQ $\left.(\mu \mathrm{g} \mathrm{L})^{-1}\right)$

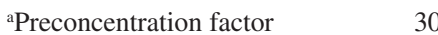

'Enhancement factor

23

*The limit of detection was also verified by the one sided student's t-test based on $\Delta \mathrm{X}_{\text {min }}: \mathrm{tS}_{\text {blank }} / \mathrm{dA} / \mathrm{dC}$ equation with relative error of $3.71 \%$ at confidence level of $99 \%$ for twelve replicate measurements (at which the critical t-value, standard deviation of blank $\left(\mathrm{S}_{\text {blank }}\right)$ and slope of calibration curve $(\mathrm{dA} / \mathrm{dC})$ are

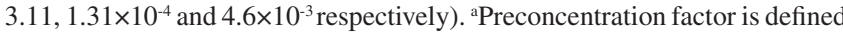
as the ratio of the initial solution volume to the volume of surfactant rich phase. bEnhancement factor is calculated as the ratio of slope of preconcentrated samples to that obtained without preconcentration.

The preconcentration factor was found to average 30 by calculating the ratio of the initial solution volume to the volume of surfactant-rich phase in the linear range $0.285-20 \mu \mathrm{g} \mathrm{L} \mathrm{L}^{-1}$. The enhancement factor measures the increase in the instrumental signal provided by the preconcentration method. One of the most reliable ways to calculate this parameter is to calculate the ratio between the slopes of the calibration curves for the procedure with and without preconcentration. Thus, obtained in this way, the improvement factor was 23 in the CPE procedure developed.

\section{Selectivity study}

The effect of potential interference of some metal ions on the preconcentration and determination of copper (II) was examined. In these experiments, solutions containing copper (II) $\left(10 \mu \mathrm{g} \mathrm{L}^{-1}\right)$ with the addition of interfering ions were treated according to the recommended CPE procedure under the optimized reagent conditions, and the results are given in Table 2 . Table 2 depicts the tolerance limits of the diverse ions, i.e. interferent-to-analyte ratios in which the relative error was less than $\pm 5.0 \%$ in terms of signal variation. Only a serious interference has been observed from $\mathrm{Hg}^{2+}, \mathrm{Ni}^{2+}$, and $\mathrm{Co}^{2+}$ ions forming a stable complex with the ligand. The interfering effect of $\mathrm{Hg}^{2+}$ ions up to150-fold excess over copper was completely negated in the presence of $0.2 \mathrm{~mL}$ of $0.05 \mathrm{~mol} \mathrm{~L}^{-1} \mathrm{Na}_{2} \mathrm{~S}_{2} \mathrm{O}_{3}$. The interference of
$\mathrm{Ni}$ (II) and $\mathrm{Co}$ (II) ions can be overcome up to $350-500$ fold by adding $0.2 \mathrm{~mL}$ of $0.05 \mathrm{~mol} \mathrm{~L}^{-1} \mathrm{Na}_{2} \mathrm{H}_{2} \mathrm{P}_{2} \mathrm{O}_{7}$ or $0.2 \mathrm{~mL}$ of $0.01 \mathrm{~mol} \mathrm{~L}^{-1}$ citric acid as masking agents. As can be seen from Table 2, it is clear that the developed method is relatively selective in terms of major species present in real samples.

Table 2. Tolerance limits of interfering ions in spectrophotometric determination of $10 \mu \mathrm{g} \mathrm{L}^{-1} \mathrm{Cu}$ (II) ion after preconcentration with $\mathrm{CPE}$ under the optimized conditions

\begin{tabular}{|c|c|}
\hline Interfering species & *Mole ratio, Interferent/analyte \\
\hline $\begin{array}{l}\mathrm{H}_{3} \mathrm{BO}_{3}, \mathrm{HCO}_{3}^{-}, \mathrm{F}^{-}, \mathrm{Cl}^{-}, \mathrm{Br}, \mathrm{HPO}_{4}^{2-} \\
\mathrm{NO}_{3}^{-} \text {and } \mathrm{SO}_{4}^{2-}\end{array}$ & $>2500$ \\
\hline $\mathrm{Mg}^{2+}, \mathrm{Ca}^{2+}, \mathrm{NH}_{4}^{+}, \mathrm{Na}^{+}$and $\mathrm{K}^{+}$ & $1250-2000$ \\
\hline Oxalate, tartrate and citrate & $1000-1500$ \\
\hline $\mathrm{Sr}^{2+}, \mathrm{Zn}^{2+}$ and $\mathrm{Al}^{3+}$ & $750-1000$ \\
\hline $\mathrm{CN}^{-}, \mathrm{HSO}_{3}^{-}$and $\mathrm{SCN}^{-}$ & $500-750$ \\
\hline $\mathrm{NO}_{2}^{-}, \mathrm{Sb}^{3+}, \mathrm{Bi}^{3+}$ and $\mathrm{Cr}^{3+}$ & $350-500$ \\
\hline $\mathrm{As}^{3+}, \mathrm{SeO}_{3}{ }^{2-}, \mathrm{Hg}_{2}{ }^{2+}$ and $\mathrm{Fe}^{2+}$ & $200-350$ \\
\hline $\mathrm{Pb}^{2+}, \mathrm{Fe}^{3+}, \mathrm{Mn}^{2+}$ and $\mathrm{Cd}^{2+}$ & $125-200$ \\
\hline${ }^{\mathrm{a}} \mathrm{Hg}^{2+},{ }^{\mathrm{b}} \mathrm{Ni}^{2+}$ and ${ }^{\mathrm{b}} \mathrm{Co}^{2+}$ & $25-75\left({ }^{\mathrm{a}} 150,{ }^{\mathrm{b}} 350-500\right)$ \\
\hline
\end{tabular}

* Highest ratio which gives an error less than $5.0 \%$ in terms of signal variation. ${ }^{a}$ Tolerance limits in the presence of $0.2 \mathrm{~mL}$ of $0.05 \mathrm{~mol} \mathrm{~L}^{-1} \mathrm{Na}_{2} \mathrm{~S}_{2} \mathrm{O}_{3}$ as masking agent. ${ }^{\mathrm{b}}$ Tolerance limits in the presence of $0.2 \mathrm{~mL}$ of $0.05 \mathrm{~mol} \mathrm{~L}^{-1}$ $\mathrm{Na}_{2} \mathrm{H}_{2} \mathrm{P}_{2} \mathrm{O}_{7}$ or $0.2 \mathrm{~mL}$ of $0.01 \mathrm{~mol} \mathrm{~L}^{-1}$ citric acid as masking agents.

\section{Analytical applications of the developed method}

For the analysis of beverage samples and CRMs, a standard calibration curve was employed. In order to establish the accuracy and precision of the proposed procedure, the method was initially applied to the determination of trace levels of copper (II) in the CRMs, SRM 1570a spinach leaves and SRM 1573a tomato leaves. The analytical results showed good consistency between the measured values $\left(12.40 \pm 0.50\right.$ and $4.70 \pm 0.12 \mathrm{ng} \mathrm{g}^{-1}$ after wet digestion with a mixture of $\mathrm{HNO}_{3}-\mathrm{HClO}_{4}(4: 1, \mathrm{v} / \mathrm{v}) ; 12.30 \pm 0.50$ and $4.65 \pm 0.13 \mathrm{ng} \mathrm{g}^{-1}$ after wet digestion with a mixture of $\left.\mathrm{HNO}_{3}-\mathrm{H}_{2} \mathrm{O}_{2}(3: 2, \mathrm{v} / \mathrm{v})\right)$ and the certified values $\left(12.20 \pm 0.60\right.$ and $\left.4.70 \pm 0.14 \mathrm{ng} \mathrm{g}^{-1}\right)$, respectively. The tabulated Student's t-values at a significance level of 0.05 were 3.18 for certified samples, and the experimental t-values were in the range 0.33-1.44, respectively. For both certified samples, the experimental values obtained are also smaller than the tabulated values, so it may be concluded that the values obtained are statistically equal to the certified values. The method was also applied to the determination of trace copper (II) in nonalcoholic and alcoholic beverage samples. The analytical results and the recoveries for the samples spiked at It can be seen that the recovery for the spiked samples is in range 98.4-100.4\% with a relative standard deviation of 2.51-3.94\% (N: 5) for wet digestion with a mixture of $\mathrm{HNO}_{3}-\mathrm{HClO}_{4}(4: 1, \mathrm{v} / \mathrm{v})$, whereas it is in range 99.0-100.6\% with relative standard deviation of $2.52-3.81 \%$ (N:5) for wet digestion with a mixture of $\mathrm{HNO}_{3}-\mathrm{H}_{2} \mathrm{O}_{2}(3: 2, \mathrm{v} / \mathrm{v})$. As can be seen from Table 3, the Student's $t$-test for comparison of mean values demonstrated that there is no significant difference between the mean values obtained by the two digestion procedures at a significance level of $0.05 .{ }^{41}$ Because the experimental t-values ranging from 0.092 to 0.271 are lower than the tabulated t-value of 2.31 , it can be concluded that the mean values obtained by the two digestion procedures include a significant difference for 8 degrees of freedom at the $95 \%$ confidence level. It is clear that the proposed method for beverage samples has good reproducibility as a measure of precision by variance analysis based on a pooled standard deviation with an experimental $\mathrm{F}_{4,4}$-value ranging from 1.05 to 1.23.

A validation study was performed to demonstrate the suitability 
Table 3. Determination of copper contents of some alcoholic and nonalcoholic beverages as well as CRMs, and recovery studies of spiked samples

\begin{tabular}{|c|c|c|c|c|c|c|c|c|c|c|c|}
\hline \multirow{2}{*}{ Samples } & \multirow{2}{*}{$\begin{array}{c}\text { Sample } \\
\text { volume, } \\
\mathrm{mL}\end{array}$} & \multicolumn{4}{|c|}{$\begin{array}{l}\text { After wet digestion with } \mathrm{HNO}_{3} / \mathrm{HClO}_{4} \\
\qquad(4: 1, \mathrm{v} / \mathrm{v})(\mathrm{N}: 5)\end{array}$} & \multicolumn{4}{|c|}{$\begin{array}{l}\text { After wet digestion with } \mathrm{HNO}_{3} / \mathrm{H}_{2} \mathrm{O}_{2} \\
\qquad(3: 2, \mathrm{v} / \mathrm{v})(\mathrm{N}: 5)\end{array}$} & \multirow[t]{2}{*}{$\begin{array}{l}\text { Certified } \\
\text { value, } \text { ng g }^{-1} \\
(\mathrm{~N}: 5)\end{array}$} & \multirow[t]{2}{*}{$\begin{array}{l}\text { The calculated } \\
\text { t- and F-values }\end{array}$} \\
\hline & & $\begin{array}{l}\text { Added, } \\
\mu \mathrm{g} \mathrm{L}^{-1}\end{array}$ & $\begin{array}{l}\text { Found, } \\
\mu \mathrm{g} \mathrm{L}^{-1}\end{array}$ & $\mathrm{RSD} \%$ & Recovery \% & $\begin{array}{l}\text { Added, } \\
\mu \mathrm{g} \mathrm{L} \mathrm{L}^{-1}\end{array}$ & $\begin{array}{l}\text { Found, } \\
\mu \mathrm{g} \mathrm{L}^{-1}\end{array}$ & RSD \% & Recovery \% & & \\
\hline \multicolumn{12}{|c|}{ *Nonalcoholic beverages } \\
\hline \multirow[t]{2}{*}{ Canned Cherry juice } & 3 & - & $13.69 \pm 0.54$ & 3.94 & - & - & $13.65 \pm 0.52$ & 3.81 & - & - & $0.120,1.08$ \\
\hline & & 5 & $18.70 \pm 0.62$ & 3.32 & 100.2 & 5 & $18.63 \pm 0.60$ & 3.22 & 99.6 & - & - \\
\hline \multirow[t]{2}{*}{ Canned Orange juice } & 3 & - & $8.72 \pm 0.30$ & 3.44 & - & - & $8.78 \pm 0.08$ & 3.19 & - & - & $0.156,1.07$ \\
\hline & & 5 & $13.65 \pm 0.38$ & 2.78 & 98.6 & 5 & $13.75 \pm 0.37$ & 2.69 & 99.4 & - & - \\
\hline \multirow{2}{*}{$\begin{array}{l}\text { Bottled Soda mixed } \\
\text { with fruit }\end{array}$} & 3 & - & $11.18 \pm 0.36$ & 3.22 & - & - & $11.20 \pm 0.35$ & 3.13 & - & - & $0.089,1.06$ \\
\hline & & 5 & $16.15 \pm 0.43$ & 2.66 & 99.4 & 5 & $16.18 \pm 0.42$ & 2.60 & 99.6 & - & - \\
\hline \multirow[t]{2}{*}{ Canned Soda } & 3 & - & $11.07 \pm 0.34$ & 3.07 & - & - & $11.13 \pm 0.36$ & 3.23 & - & - & $0.271,1.12$ \\
\hline & & 5 & $16.05 \pm 0.41$ & 2.55 & 99.6 & 5 & $16.10 \pm 0.42$ & 2.61 & 99.4 & - & - \\
\hline \multirow[t]{2}{*}{ Canned Apricot juice } & 3 & - & $14.40 \pm 0.42$ & 2.92 & - & - & $14.37 \pm 0.40$ & 2.78 & - & - & $0.116,1.10$ \\
\hline & & 5 & $19.35 \pm 0.58$ & 3.00 & 99.0 & 5 & $19.40 \pm 0.56$ & 2.89 & 100.6 & - & - \\
\hline \multirow[t]{2}{*}{ Canned Apple juice } & 3 & - & $12.08 \pm 0.36$ & 2.98 & - & - & $12.13 \pm 0.40$ & 3.30 & - & - & $0.208,1.23$ \\
\hline & & 5 & $17.04 \pm 0.45$ & 2.64 & 99.2 & 5 & $17.08 \pm 0.43$ & 2.52 & 99.0 & - & - \\
\hline \multicolumn{12}{|c|}{${ }^{\mathrm{a}}$ Alcoholic beverages } \\
\hline \multirow[t]{2}{*}{ White wine } & 5 & - & $11.74 \pm 0.36$ & 3.07 & - & - & $11.78 \pm 0.35$ & 2.97 & - & - & $0.178,1.06$ \\
\hline & & 5 & $16.72 \pm 0.42$ & 2.51 & 99.6 & 5 & $16.75 \pm 0.43$ & 2.57 & 99.4 & - & - \\
\hline \multirow[t]{2}{*}{ Red wine } & 5 & - & $13.79 \pm 0.42$ & 3.05 & - & - & $13.83 \pm 0.43$ & 3.11 & - & - & $0.148,1.05$ \\
\hline & & 5 & $18.76 \pm 0.52$ & 2.77 & 99.4 & 5 & $18.78 \pm 0.53$ & 2.82 & 99.0 & - & - \\
\hline \multirow{2}{*}{$\begin{array}{l}\text { Efes Pilsener, Bottled } \\
\text { Beer }\end{array}$} & 4 & - & $11.65 \pm 0.35$ & 3.00 & - & - & $11.68 \pm 0.34$ & 2.91 & - & - & $0.092,1.06$ \\
\hline & & 5 & $16.57 \pm 0.53$ & 3.20 & 98.4 & 5 & $16.63 \pm 0.50$ & 3.01 & 99.0 & - & - \\
\hline \multirow{2}{*}{$\begin{array}{l}\text { Marmara Gold, Bottled } \\
\text { Beer }\end{array}$} & 4 & - & $10.48 \pm 0.30$ & 2.86 & - & - & $10.51 \pm 0.31$ & 2.95 & - & - & $0.156,1.07$ \\
\hline & & 5 & $15.43 \pm 0.45$ & 2.92 & 99.0 & 5 & $15.46 \pm 0.43$ & 2.78 & 99.0 & - & - \\
\hline \multicolumn{12}{|c|}{${ }^{\mathrm{b}} \mathrm{CRMs}(\mathrm{N}: 4)$} \\
\hline $\begin{array}{l}\text { SRM 1570a (Spinach } \\
\text { leaves) }\end{array}$ & - & & $12.40 \pm 0.50$ & 4.03 & 98.9 & - & $12.30 \pm 0.50$ & 4.07 & 100.8 & $12.20 \pm 0.60$ & $\begin{array}{l}0.80,144 \\
0.40,1.44\end{array}$ \\
\hline $\begin{array}{l}\text { SRM 1573a (Tomato } \\
\text { leaves) }\end{array}$ & - & & $4.72 \pm 0.12$ & 2.54 & 100.4 & - & $4.65 \pm 0.13$ & 2.80 & 98.9 & $4.70 \pm 0.14$ & $\begin{array}{l}0.33,1.36 \\
0.77,1.16\end{array}$ \\
\hline
\end{tabular}

${ }^{\mathrm{a}}$ In order to compare two mean values the statistical t- and F-critical values at $95 \%$ confidence level and 8 degrees of freedom are 2.31 and 6.39 , respectively. ${ }^{\mathrm{b}}$ In order to compare the measured value with the certified values of CRMs the critical t- and F- values at $95 \%$ confidence level and degrees of freedom of 3 are 3.18 and 8.53 , respectively.

of the analytical method for the intended purpose and therefore the reliability of the results. Linearity, limits of detection and quantification, accuracy, inter-day and intra-day method precision, and instrumental precision for standards and samples were tested by employing two CRMs: SRM 1573a tomato leaves and SRM 1570a spinach leaves. The certified contents were $4.70 \pm 0.14$ and $12.20 \pm 0.60$ $\mathrm{ng} \mathrm{g}^{-1}$ for tomato and spinach leaves, respectively. It can be said that the obtained values, $4.70 \pm 0.12$ and $4.65 \pm 0.13 \mathrm{ng} \mathrm{g}^{-1}$ for $\mathrm{HNO}_{3} / \mathrm{HClO}_{4}$ and $12.40 \pm 0.50$ and $12.30 \pm 0.50 \mu \mathrm{g} \mathrm{g}^{-1}$ for $\mathrm{HNO}_{3} / \mathrm{H}_{2} \mathrm{O}_{2}$, respectively, using two wet digestion procedures are quantitatively consistent with the certified values. In addition, standard additions were performed at three concentration levels ranging from 5 to $15 \mu \mathrm{g} \mathrm{L} \mathrm{L}^{-1}$ for copper in order to determine if there is a possible systematic error arising from beverage samples with a high alcohol content such as especially wine. Validation parameters are summarized in Table 4. It is clear that the analytical data obtained with twelve replicate measurements show a good performance of the method for the intended purpose in terms of accuracy and precision.

For comparative purposes, the performance characteristics of the proposed method and other selected preconcentration methods previously reported in the literature are given in Table 5. As can be seen from Table 5, the detection limit and preconcentration or enrichment factor for the method are lower than those given by many methods reported in literature. ${ }^{29-32,42-49}$ except for those of the method developed

Table 4. The main validation parameters for spectrophotometric copper measurement in beverages at $537 \mathrm{~nm}$ after preconcentration with CPE

\begin{tabular}{|c|c|c|c|c|c|c|c|c|c|c|c|}
\hline \multirow{3}{*}{$\begin{array}{c}\text { Validation } \\
\text { parameters }\end{array}$} & \multirow{2}{*}{$\begin{array}{l}\text { Standards } \\
\text { linearity }\end{array}$} & \multirow{2}{*}{$\begin{array}{l}\text { Samples } \\
\text { linearity }\end{array}$} & \multirow{2}{*}{$\begin{array}{l}\text { Standards } \\
\text { accuracy }\end{array}$} & \multirow{2}{*}{$\begin{array}{c}\text { Samples ac- } \\
\text { curacy }\end{array}$} & \multicolumn{4}{|c|}{ Method precision } & \multirow{2}{*}{$\begin{array}{c}\text { Instrumental } \\
\text { precision }\end{array}$} & \multirow{2}{*}{$\begin{array}{l}\text { Limit of } \\
\text { detection }\end{array}$} & \multirow{2}{*}{$\begin{array}{l}\text { Limit of } \\
\text { quantifi- } \\
\text { cation }\end{array}$} \\
\hline & & & & & $\begin{array}{c}\text { Intra-assay } \\
\text { day } 1 \\
\end{array}$ & $\begin{array}{c}\text { Intra-assay } \\
\text { day } 2 \\
\end{array}$ & $\begin{array}{c}\text { Intra-assay } \\
\text { day } 3 \\
\end{array}$ & Intermediate & & & \\
\hline & $\begin{array}{c}\mathrm{a} \pm \mathrm{L} \cdot \mathrm{C} \\
\mathrm{b} \pm \mathrm{L} \cdot \mathrm{C} \\
\mathrm{r}^{2} \\
\end{array}$ & $\begin{array}{c}\mathrm{a} \pm \mathrm{L} \cdot \mathrm{C} \\
\mathrm{b} \pm \mathrm{L} \cdot \mathrm{C} \\
\mathrm{r}^{2} \\
\end{array}$ & $\begin{array}{c}\text { Recovery } \% \\
\text { RSD \% }\end{array}$ & $\begin{array}{c}\text { Recovery } \% \\
\text { RSD } \%\end{array}$ & $\begin{array}{c}\text { Mean, } \mu \mathrm{g} \mathrm{L}^{-1} \\
\text { RSD } \%\end{array}$ & $\begin{array}{c}\text { Mean, } \mu \mathrm{g} \mathrm{L}^{-1} \\
\operatorname{RSD} \%\end{array}$ & $\begin{array}{c}\text { Mean, } \mu \mathrm{g} \mathrm{L}^{-1} \\
\operatorname{RSD} \%\end{array}$ & $\begin{array}{c}\text { Mean, } \mu \mathrm{g} \mathrm{L}^{-1} \\
\text { RSD \% }\end{array}$ & $\begin{array}{c}\text { Mean, } \mu \mathrm{g} \mathrm{L}^{-1} \\
\text { RSD } \%\end{array}$ & $\begin{array}{c}\text { Concen- } \\
\text { tration, } \\
\mu \mathrm{g} \mathrm{L}^{-1}\end{array}$ & $\begin{array}{c}\text { Concen- } \\
\text { tration, } \\
\mu \mathrm{g} \mathrm{L}^{-1}\end{array}$ \\
\hline \multirow{3}{*}{$\begin{array}{l}\text { After wet digestion } \\
\text { with } \mathrm{HNO}_{3} / \mathrm{H}_{2} \mathrm{O}_{2} \\
(3: 2, \mathrm{v} / \mathrm{v})\end{array}$} & $0.126 \pm 0.0013$ & $0.833 \pm 0.0070$ & $98.6 \pm 1.6$ & $96.5 \pm 2.0$ & $13.8 \pm 0.5$ & $13.6 \pm 0.5$ & $13.7 \pm 0.7$ & $13.7 \pm 0.6$ & $13.6 \pm 0.4$ & 0.085 & 0.28 \\
\hline & $0.046 \pm 0.0018$ & $0.053 \pm 0.0021$ & 1.95 & 3.85 & 3.6 & 3.7 & 5.1 & 4.4 & 2.94 & - & - \\
\hline & 0.9968 & 0.9972 & - & - & - & - & - & - & - & - & - \\
\hline \multirow{3}{*}{$\begin{array}{c}\text { After wet digestion } \\
\text { with } \mathrm{HNO}_{3} / \mathrm{HClO}_{4} \\
(4: 1, \mathrm{v} / \mathrm{v})\end{array}$} & $0.124 \pm 0.0015$ & $0.836 \pm 0.0078$ & $97.6 \pm 2.3$ & $96.4 \pm 2.5$ & $13.7 \pm 0.5$ & $13.6 \pm 0.6$ & $13.5 \pm 0.8$ & $13.6 \pm 0.7$ & $13.5 \pm 0.5$ & 0.1 & 0.33 \\
\hline & $0.045 \pm 0.0021$ & $0.054 \pm 0.0025$ & 2.10 & 3.95 & 3.65 & 4.41 & 5.92 & 5.18 & 3.70 & - & - \\
\hline & 0.9968 & 0.9972 & - & - & - & - & - & - & - & - & - \\
\hline
\end{tabular}

a: intercept (Absorbance); b: slope (Absorbance. $\mathrm{L} \mathrm{\mu g}^{-1}$ ); L.C: limits of confidence at probability level of 0.05 for twelve replicate measurements (N: 12) of wine sample based on direct calibration curve and standard addition calibration curve approaches. 
Table 5. Comparison of the presented CPE method with other reported preconcentration methods for determination of $\mathrm{Cu}_{\text {at }}$ levels of $\mu \mathrm{g} \mathrm{L}^{-1}$

\begin{tabular}{|c|c|c|c|c|c|c|c|c|c|}
\hline $\begin{array}{c}\text { Chelating } \\
\text { agent }\end{array}$ & Micellar system & $\begin{array}{c}\text { Surfactant-rich phase } \\
\text { diluting agent }\end{array}$ & Detection system & $\begin{array}{l}\text { Linear range, } \\
\qquad \mu \mathrm{g} \mathrm{L}^{-1}\end{array}$ & $\begin{array}{l}\mu \text { tection limit, } \\
\mu \mathrm{g} \mathrm{L}^{-1}\end{array}$ & $\begin{array}{c}\text { RSD } \\
\%\end{array}$ & $\begin{array}{l}\text { Preconcentration } \\
\text { factor }\end{array}$ & Matrix & References \\
\hline Dithizone & Triton X-114 & THF & Spectrophotometry & $15-250$ & 4.6 & $2.9-3.5$ & - & Cow liver samples & 29 \\
\hline HEPTS & Triton X-114 & $2 \mathrm{~mL}$ methanol & Spectrophotometry & $0.1-25$ & 0.1 & 0.9852 & - & $\begin{array}{l}\text { Water and saturated } \\
\text { saline samples }\end{array}$ & 30 \\
\hline 4-BPDC & Triton X-114 & - & Spectrophotometry & $5-200$ & 1.6 & 2.8 & - & Water samples & 31 \\
\hline Isoleucine & Triton X-114 & $1.0 \mathrm{~mL}$ methanol & Spectrophotometry & $10-1000$ & 5.0 & 2.8 & $22^{\mathrm{b}}$ & $\begin{array}{c}\text { Food and water } \\
\text { samples }\end{array}$ & 32 \\
\hline $\mathrm{Me}-\mathrm{BTABr}$ & Triton X-114 & $\begin{array}{c}200 \mu \mathrm{L} \text { methanol } \\
\text { solution of } 1.0 \mathrm{~mol} \mathrm{~L}^{-1} \\
\mathrm{HNO}_{3} \\
\end{array}$ & FAAS & $1.08-100$ & 1.08 & 2.6 & $17^{\mathrm{a}}$ & Water samples & 38 \\
\hline NDTT & Triton X-114 & $\begin{array}{c}200 \mu \mathrm{L} \text { methanol } \\
\text { solution of } 0.1 \mathrm{~mol} \mathrm{~L}^{-1} \\
\mathrm{HNO}_{3}\end{array}$ & FAAS & $0.22-100$ & 0.22 & 2.1 & $22.4^{\mathrm{b}}$ & $\begin{array}{l}\text { Environmental water } \\
\text { samples }\end{array}$ & 42 \\
\hline Cupron & Triton X-114 & $\begin{array}{c}800 \mu \mathrm{L} \text { methanol } \\
\text { solution of } 0.1 \mathrm{~mol} \mathrm{~L}^{-1} \\
\mathrm{HNO}_{3}\end{array}$ & FAAS & $0.05-50$ & 0.04 & 1.9 & $88^{\mathrm{b}}$ & $\begin{array}{l}\text { River water and } \\
\text { seawater samples }\end{array}$ & 44 \\
\hline Me-BDBD & Triton X-114 & $\begin{array}{c}200 \mu \mathrm{L} \text { methanol } \\
\text { solution of } 1.0 \mathrm{~mol} \mathrm{~L}^{-1} \\
\mathrm{HNO}_{3}\end{array}$ & FAAS & $1.5-100$ & 1.5 & 2.3 & $14^{\mathrm{a}}$ & Water samples & 45 \\
\hline Thiamine & Triton X-114 & $\begin{array}{l}\text { At } 2.5 \mathrm{~mL} \text { with etha- } \\
\text { nol/water }(1: 1)\end{array}$ & Spectrofluorimetry & $1-250$ & 0.29 & 2.12 & $10^{\mathrm{b}}$ & $\begin{array}{l}\text { Water samples and } \\
\text { parenteral solutions }\end{array}$ & 46 \\
\hline Alizarin S & Triton X-114 & $\begin{array}{c}1 \mathrm{~mL} \text { methanol } \\
\text { solution of } 0.1 \mathrm{~mol} \mathrm{~L}^{-1} \\
\mathrm{HNO}_{3}\end{array}$ & FAAS & $5-200$ & 1.07 & 2.1 & $21^{\mathrm{a}}$ & Water samples & 47 \\
\hline PTU & Triton X-114 & $\begin{array}{l}0.5 \mathrm{~mL}_{0.5 \mathrm{~mol} \mathrm{~L}^{-1}} \\
\mathrm{HNO}_{3} \text { in methanol }\end{array}$ & FAAS & - & 1.6 & $<1.4$ & $30^{\circ}$ & $\begin{array}{l}\text { Environmental } \\
\text { samples }\end{array}$ & 48 \\
\hline MPMP & Triton X-114 & $\begin{array}{l}300 \mu \mathrm{L} \text { methanol solu- } \\
\text { tion } 1.0 \mathrm{~mol} \mathrm{~L}^{-1} \mathrm{HNO}_{3}\end{array}$ & FI-FAAS & $1-150$ & 0.15 & 1.8 & $81^{\mathrm{a}}$ & $\begin{array}{l}\text { Rice flour and water } \\
\text { samples }\end{array}$ & 49 \\
\hline DDTC & $\begin{array}{l}\text { Triton X-100/ } \\
\text { Octanol }\end{array}$ & $3.0 \mathrm{~mL}$ ethanol & Spectrophotometry & $0.4-50$ & 0.4 & 3.7 & $18^{\mathrm{a}}$ & $\begin{array}{c}\text { Lake water and tap } \\
\text { water }\end{array}$ & 50 \\
\hline Sudan II & $\begin{array}{l}\text { Triton X-114/ } \\
\text { SDS }\end{array}$ & $1.0 \mathrm{~mL}$ Acetone & Spectrophotometry & $0.285-20$ & 0.085 & $2.25-3.21$ & $23^{\mathrm{a}}, 30^{\mathrm{b}}$ & Beverage samples & This study \\
\hline
\end{tabular}

Dithizone 1,5-diphenylthiocarbazone, THF Tetrahydrofuran, Cupron 1,5-diphenyl-benzoin, Thiamine 2-[3-[(4-Amino-2-methyl-pyrimidin-5-yl)methyl]4-methyl-thiazol-5-yl] ethanol, 4-BPDC 4-bencylpiperidineditiocarbamate, HEPTS 4-ethyl-1-(pyridin-2-yl)thiosemicarbazide, Me-BDBD 6-[2'-(6'-methylbenzothiazolylazo)]-1,2-dihydroxy-3,5-benzenedisulfonic acid, Me-BTABr 2-[2'-(6-methyl-benzothiazolylazo)]-4-bromophenol, NDTT 6-(2-naphthyl)-2,3dihydro-as-triazine-3-thione, Alizarin S 1,2-dihydroxyanthraquinone-3-sulfonic acid sodium salt, PTU 4-hydroxy-2-mercapto-6-propylpyrimidine, MPMP 2-[(2-mercaptophenylimino)-methyl] phenol, DDTC diethyldithiocarbamate, Sudan II 2,4-dimethyl 1-phenylazo-2-naphthol, SDS sodium dodecyl sulfate, FI-FAAS

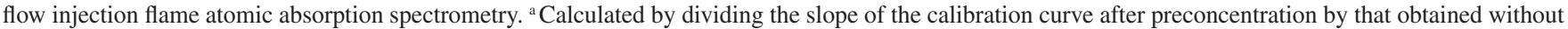
preconcentration. ${ }^{\mathrm{b}}$ Calculated as the ratio of concentration of the analyte in the final surfactant-rich phase to that in the initial solution. ${ }^{\mathrm{c}}$ No definition available.

by Goudarzi. ${ }^{50}$ It is important to emphasize that $1.0-\mathrm{mL}$ acetone volume containing a surfactant-rich phase was sufficient to obtain an enhancement factor of 23 , and the whole preconcentration procedure was performed simply in a 50-mL centrifuge tube within $20 \mathrm{~min}$.

\section{CONCLUSIONS}

The results of this study indicate the usefulness of the proposed $\mathrm{CPE} /$ spectrophotometric method for the quantitative extraction of $\mathrm{Cu}$ present in different beverage samples. The proposed method allows $\mathrm{Cu}$ determination at $0.085 \mu \mathrm{g} \mathrm{L}^{-1}$ levels in a linear range $0.285-20 \mu \mathrm{g}$ $\mathrm{L}^{-1}$, thus representing a promising approach in the monitoring of $\mathrm{Cu}$ in different beverage samples with low cost, simplicity, efficiency, versatility, and non-polluting respect. The proposed CPE method gives highly low limits of detection (LOD), high preconcentration/ enhancement factors, and good relative standard deviation (RSD) for extraction of the copper with mixed surfactant, Triton X-114 plus SDS from its initial matrix after pretreatment with two wet digestion procedures. Due to its versatility, the technique can also be applied to the monitoring of copper in various samples of environmental, toxicological, and medical analysis as well as beverage samples. The method can be considered as an alternative tool to sensitive but expensive, time-consuming, and expert-user-requiring analytical techniques such as spectrofluorimetry, FAAS, ICP-MS, ICP-AES, and GF-AAS.

\section{ACKNOWLEDGEMENTS}

The authors are grateful to the Cumhuriyet University Scientific Research Projects (CUBAP) Commission for partly supporting the present study. Authors wish also to acknowledge Professor M. Akçay for his expert discussions in the preparation of this manuscript.

\section{REFERENCES}

1. Theophanides, T.; Anastassopoulou, J.; J. Crit. Rev. Oncol. Hematol. 2002, 42, 57.

2. Onianwa, P.C.; Adeyemo, A.O.; Idowu, O.E.; Ogabiela, E. E.; Food Chem. 2001, 72, 89 .

3. Lopes, C. M. P. V.; Almeida, A.A.; Santos, J. L. M.; Lima, J. L. F. C.; Anal. Chim. Acta 2006, 555, 370.

4. Doner, G.; Ege, A.; Anal. Chim. Acta 2005, 547, 14.

5. Mendiguchı, C.; Moreno, C.; Garcı-Vargas, M.; Anal. Chim. Acta 2002, 460, 35 .

6. Taher, M.A.; Mobarakeh, S.Z.M.; Mohadesi, A.R.; Turk. J. Chem. 2005, 29, 17.

7. Pinto, J.J.; Moreno, C.; García-Vargas, M.; Talanta 2004, 64, 562.

8. Allen, L.B.; Sitonen, P.H.; Thompson, Jr. H.C.; J. Agric. Food. Chem. 1997, 45, 162.

9. Rao, K.S.; Balaji, T.; Raoc, T.P.; Babud, Y.; Naidu, G.R.K.; Spectrochim. Acta $B$ 2002, 57, 1333. 
10. Becker, J.S.; Zoriy, M.; Pickhardt, C.; Damoc, E.; Juhacz, G.; Palkovits, M.; Przybylski, M.; Anal. Chem. 2005, 77, 5851.

11. Lin, T.W.; Huang, S.D.; Anal. Chem. 2001, 73, 4319.

12. Alvarez, J.; Marco, L.M.; Arroyo, J.; Greaves, E.D.; Rivas, R.; Spectrochim. Acta B 2003, 58, 2183.

13. Celik, U.; Oehlenschláger, J.; Food Chem. 2004, 87, 343.

14. Garcīa, J.C.R.; Garcīa, J.B.; Latorre, C.H.; Martïn, S.G.; Crecente, R.M.P.; J. Agric. Food Chem. 2005, 53, 6616.

15. Fathi, S.A.M.; Yaftian, M.R.; J. Colloid Interf. Sci. 2009, 334, 167.

16. Es'haghi, Z.; Azmoodeh, R.; Arab. J. Chem. 2010, 3, 21.

17. Fathi, S.A.M.; Yaftian, M.R.; J. Hazard. Mater. 2009, 164, 133.

18. Huang, G.G.; Yang, J.; Anal. Chem. 2003, 75, 2262.

19. Diniz, M.C.T.; Filho, O.F.; Rohwedder, J.J.R.; Anal. Chim. Acta 2004, $525,281$.

20. Rezaei, B.; Sadeghi, E.; Meghdadi, S.; J. Hazard. Mater. 2009, 168, 787.

21. Manzoori, J.L.; Bavili-Tabrizi, A.; Microchem. J. 2002, 72, 1.

22. Shokrollahi, A.; Ghaedi, M.; Hossaini, O.; Khanjaria, N.; Soylak, M.; J. Hazard. Mater. 2008, 160, 435.

23. Divrikli, U.; Kartal, A.A.; Soylak, M.; Elci, L.; J. Hazard. Mater. 2007, $145,459$.

24. Kunio, O.; Masea, M.; Fumihiko, Y.; Isoshi, N.; Ryoei, I.; Analyst 1990, $115,23$.

25. Tatara, E.; Materna, K.; Schaadt, A.; Bart, H.J.; Szymanowski, J.; Environ. Sci. Technol. 2005, 39, 3110.

26. Bellato, A.C.S.; Gervasio, A.P.G.; Gine, M.F.; J. Anal. Atom. Spectrom. 2005, 20, 535 .

27. Silva, E.L.; Roldan, P.S.; J. Hazard. Mater. 2009, 161, 142.

28. Stalikas, C.D.; Trac-Trend. Anal. Chem. 2002, 21, 343.

29. Manzoori, L.J.; Karim-Nezhat, G.; Iran J. Chem. Eng. 2005, 24, 47.

30. Hassanien, M.M.; Abdel-Rhman, M.H.; El-Asmy, A.A.; Chem. AnalWarsaw 2007, 52, 327.

32. Liang, P.; Yang, J.; J. Food Compos. Anal. 2010, 23, 95.
33. Prohaska, C.; Pomazal, K.; Steffan, I.; Fresen. J. Anal. Chem. 2000, 367, 479.

34. Gilani, A.G.; Moradi, E.; Binay, S.; Moghadam, M.; Spectrochim. Acta A 2012, 87, 112.

35. Kallury, K.; Gleeson, J.P.; Garriques, M.; LC GC N. Am. 2007, 25, 49.

36. Wu, L.P.; Li, Y.F.; Huang, C.Z.; Zhang, Q.; Anal. Chem. 2006, 78, 5570.

37. Kitagawa, S.; Munakata, M.; Higashine, A.; Inorg. Chim. Acta 1984, 84, 79.

38. Hatem, H.; Isabelle, D.B.; Monique, P.; Roger, L.; J. Org. Chem. 2004, $69,6521$.

39. J. Huo, J.; Guo, Y.; Meng, S.; Wang, M.; Wang, Y.; Complex formation of Sudan I with $\mathrm{Cu}(\mathrm{II})$ and its identification from chilli species, Bioinformatics and Biomedical Engineering (iCBBE), 4th International Conference held in Chengdu, China, 18-20 June 2010, pages: 1-4.

40. Sosa Ferrera, Z.; Padrón Sanz, C.; Mahugo Santana, C.; Santana Rodríguez, J.J.; Trac-Trend. Anal. Chem. 2004, 23, 469.

41. Miller, J.N.; Miller, J.C.; Statistics and Chemometrics for Analytical Chemistry (5th edition) Pearson Education Ltd., Chapter 3, pages: 4145, Essex, 2005.

42. Lemos, V.A.; Santos, J.S.; Baliza, P.X.; J. Braz. Chem. Soc. 2006, 17, 30.

43. Biparva, P.; Hadjmohammadi, M.R.; Acta Chim. Slov. 2007, 54, 805.

44. Wen, X.; Ye, L.; Deng, Q.; Peng, L.; Spectrochim. Acta A 2011, 83, 259.

45. Lemos, V.A.; Santos, M.S.; Dos Santos, M.J.S.; Vieira, D.R.; Novaes, C.G.; Microcim. Acta 2007, 157, 215.

46. Tabrizi, A.B.; J. Hazard. Mater. 2007, 139, 260.

47. Satıroglu, N.; Arpa, C.; Microchim. Acta 2008, 162, 107.

48. Shokrollahi, A.; Ghaedi, M.; Gharaghani, S.; Fathi, M.R.; Soylak, M.; Quim. Nova 2008, 31, 70 .

49. Baghban, N.; Shabani, A.M.H.; Dadfarnia, S.; Jafari, A.A.; Croat. Chem. Acta 2012, 85, 85.

50. Goudarzi, N.; J. Braz. Chem. Soc. 2007, 18, 1348. 